\title{
Alkaline Gel Electrophoresis Assay to Detect DNA Strand Breaks and Repair Mechanisms in Escherichia coli
}

\author{
José Carlos Pelielo de Mattos*, Ellen Serri da Motta, Márcia Betania Nunes de Oliveira, \\ Flávio José da Silva Dantas and Adriano Caldeira de Araujo \\ Laboratório de Radio e Fotobiologia; Departamento de Biofísica e Biometria; Universidade do Estado do Rio de \\ Janeiro; Av. 28 de Setembro, 87; 20551030; jcmattos@uerj.br; Rio de Janeiro - RJ - Brasil
}

\begin{abstract}
Reactive oxygen species (ROS) can induce lesions in different cellular targets, including DNA. Stannous chloride $\left(\mathrm{SnCl}_{2}\right)$ is a $\mathrm{ROS}$ generator, leading to lethality in Escherichia coli (E. coli), with the base excision repair (BER) mechanism playing a role in this process. Many techniques have been developed to detect genotoxicity, as comet assay, in eukaryotic cells, and plasmid DNA agarose gel electrophoresis. In this study, an adaptation of the alkaline gel electrophoresis method was carried out to ascertain the induction of strand breaks by $\mathrm{SnCl}_{2}$ in bacterial DNA, from E. coli BER mutants, and its repair pathway. Results obtained show that $\mathrm{SnCl}_{2}$ was able to induce DNA strand breaks in all strains tested. Moreover, endonuclease IV and exonuclease III play a role in DNA repair. On the whole, data has shown that the alkaline gel electrophoresis assay could be used both for studying DNA strand breaks induction and for associated repair mechanisms.
\end{abstract}

Keywords: Alkaline gel electrophoresis, Escherichia coli, base excision repair, stannous chloride, DNA strand breaks, reactive oxygen species

\section{INTRODUCTION}

Several studies have pointed out that reactive oxygen species (ROS) can generate lesions in many cellular structures, including DNA (Marnett, 2000; Cooke et al., 2003; Halliwell and Whiteman, 2004). Among the ROS, hydroxyl radical $\left(\mathrm{OH}^{\circ}\right)$ has been described as a powerful oxidant, able to react with any molecule (Friedberg et al., 2006). Some authors have suggested that transition metals (Asad and Leitão, 1991; Kehrer, 2000), such as $\mathrm{Fe}(\mathrm{II})$, take part, as reducing agents, in $\mathrm{OH}^{\bullet}$ formation through a Fenton reaction, a phenomenon also observed, in a Fenton-like reaction, with $\mathrm{Cu}(\mathrm{I})$ ions. Dantas and collaborators
(1996) have described that stannous chloride $\left(\mathrm{SnCl}_{2}\right)$ is also able to produce ROS in a Fentonlike reaction. In the same article, the authors, by using ROS scavengers and antioxidant enzymes, have concluded that $\mathrm{SnCl}_{2}$ induces lethality in Escherichia coli (E. coli), through ROS generation.

In time, many techniques were developed to detect DNA lesions, as any damage to this structure, if not repaired, could lead to cell death. The comet assay is one of the well-accepted tests that is widely used in different research areas including biomonitoring, routine genotoxicity assessment, and studies of DNA repair processes (Tice et al., 2000). This single-cell gel electrophoresis

\footnotetext{
Author for correspondence
} 
technique was developed by Ostling and Johanson (1984) and Singh et al. (1988). It is a simple method for measuring DNA strand breaks in eukaryotic cells. Briefly, cells embedded in agarose on a microscope slide are lysed with detergent and high salt to form nucleoids containing supercoiled loops of DNA linked to the nuclear matrix. Electrophoresis at high $\mathrm{pH}$ results in structures resembling comets, observed by fluorescence microscopy; the intensity of the comet tail relative to the head reflects the number of DNA breaks. The likely basis for this is that loops containing a break lose their supercoiling and become free to extend toward the anode. The sensitivity and specificity of the assay could be greatly enhanced if the nucleoids are incubated with bacterial repair endonucleases that recognize specific kinds of damage in the DNA and convert lesions to DNA breaks, increasing the amount of DNA in the comet tail. On the other hand, DNA repair can be monitored by incubating cells after treatment with damaging agent and measuring the damage remaining at intervals (Tice et al., 2000). Relative to other genotoxicity tests, the advantages of the comet assay include its demonstrated sensitivity for detecting low levels of DNA damage, the requirement for small numbers of cells per sample, its flexibility, its low costs, its ease of application, and the short time needed to complete a study.

Agarose gel electrophoresis could also be used to observe genotoxic lesions, in vitro, through plasmid topology alteration. Plasmids are circular minichromosomes found in bacteria and in a number other organisms. The protocol assay is based on conformational differences between plasmid molecules. The supercoiled form (or form I) can be maintained only if both polynucleotide strands are intact, providing for a more compact topology that migrates faster in the gel. If one of the double strands is broken, the plasmid will take on another conformation, called open circle (or form II), and will display a slower migration pattern on agarose gel electrophoresis. Furthermore, the linear conformation (or form III) could appear if breaks occur in the same position on both strands, also leading to a variation in migration through agarose gel, which is slower than the supercoiled form and faster than the open circle form. The test is based on the plasmid incubation with a known break-inducing agent such as $\mathrm{SnCl}_{2}$ as a positive control. Then, tested products (artificial or natural) can be used alone or in combination (De Mattos et al., 2004).

Lesions leading to cell inactivation in prokaryotes could be, for instance, alkali-labile sites and strand breaks, which can be detected by alkaline sucrose gradient (MacGrath and Williams, 1966). This experimental procedure follows many detailed steps and requires special care and supplies, including radionuclide manipulation. Therefore, we have proposed, in the present paper, a faster and easier methodology, named bacterial alkaline gel electrophoresis, adapted from Zirkle and Krieg (1996). This assay allows visualizing not only strand breaks and alkali-labile sites, but also following DNA lesions repair kinetics. Thus, we decided to use this procedure, in order to investigate genotoxicity and repair activity, using $\mathrm{SnCl}_{2}$, as positive control, and E. coli base excision repair.

Stannous chloride $\left(\mathrm{SnCl}_{2}\right)$ is used in different areas of human daily life, for example in nuclear medicine as a reducing agent of technetium-99m, with the aim to radiolabel pharmaceutical products (Saha, 1998; Santos-Filho et al., 2007). The $\mathrm{SnCl}_{2}$ biological effects have been studied by many authors in the last decade (Caldeira-de-Araujo et al., 1996; Cabral et al., 1998; Dantas et al., 1999; De Mattos et al., 2000; De Mattos et al., 2005).

\section{MATERIALS AND METHODS}

\section{Chemicals}

Stannous chloride $\left(\mathrm{SnCl}_{2} \cdot 2 \mathrm{H}_{2} \mathrm{O}\right)$ and sodium dodecyl sulfate (SDS) were acquired from Sigma Chemical Co. (USA). Sodium chloride and ethylene diaminetetracetic acid (EDTA) were obtained from Lafan (Brazil). Sodium hydroxide $(\mathrm{NaOH})$ and Tris (hydroxymethyl) amino-methane were obtained from Nuclear (Brazil). Normal point agarose (NPA), low-melting point agarose (LMPA) and ethidium bromide were acquired from Invitrogen (Brazil).

\section{Bacterial strains}

The strains used and their relevant genetic characteristics for this work are listed in Table 1. 
Table 1 - Escherichia coli K12 strains and their relevant genetic characteristics for this study.

\begin{tabular}{ccc}
\hline Strains & Relevant genetic characteristics & Source \\
\hline AB1157 & Wild type & Our laboratory \\
BW527 & $n f o$ (endonuclease IV) & B. Weiss - Atlanta - USA \\
BW9091 & $x t h$ A (exonuclease III) & B. Weiss - Atlanta - USA \\
\hline
\end{tabular}

\section{Growth medium}

Bacterial cells were grown overnight at $37^{\circ} \mathrm{C}$, with shaking in LB medium (Luria and Burrous, 1957). A starting culture for experiments was taken from overnight samples, and the cells were grown in the same medium up to exponential phase $\left(1-2 \times 10^{8}\right.$ cell $/ \mathrm{ml})$, harvested by centrifugation $(2,940 \mathrm{xg} ; 15$ $\min ; 4^{\circ} \mathrm{C}$; washed twice) and suspended in $0.9 \%$ $\mathrm{NaCl}$.

\section{Alkaline gel electrophoresis}

Alkaline gel electrophoresis was done as described by Zirkle and Krieg (1996), with modifications. All E. coli cell cultures assayed, at exponential growth phase, were separated in two samples, each one containing $1.5 \mathrm{ml}$, with exception to AB1157 cells, whose samples contained $6 \mathrm{ml}$, on account of the repair kinetics study. One fraction, control, was incubated with $\mathrm{NaCl}(0.9 \%)$ at $37^{\circ} \mathrm{C}$, by shaking, for $40 \mathrm{~min}$; the second one was incubated with $\mathrm{SnCl}_{2}(25 \mu \mathrm{g} / \mathrm{ml})$, under the same conditions. After this period, $1.5 \mathrm{ml}$ from each fraction was centrifuged ( $1 \mathrm{~min} ; 12,000 \mathrm{xg}$; room temperature) and suspended in $10 \mu \mathrm{l}$ of cold TE $\left(50 \mathrm{mM}\right.$ Tris ${ }^{\bullet} \mathrm{Cl}$ pH 8.0; 5 mM EDTA pH 8.0). Following, $50 \mu \mathrm{l}$ of low melting point agarose $\left(1.5 \%\right.$, in TE), at $37^{\circ} \mathrm{C}$, were added to each $10 \mu \mathrm{l}$ sample. The mixture (60 $\mu \mathrm{l})$ was placed in an acrylic container holding small squared wells and incubated, at room temperature, for $30 \mathrm{~min}$ to form $0.5 \mathrm{~cm}^{2}$ squared blocks. Following gellification, the blocks were incubated for $2 \mathrm{~h}$, at room temperature, in the dark, in a lysing solution (0.1 mM EDTA pH 8.0; $0.5 \mathrm{M}$ $\mathrm{NaOH} ; 0.05 \%$ SDS). Then, the blocks were washed three times $(5 \mathrm{~min}$ each) in cold TE $(1 \mathrm{ml})$ and placed onto the teeth combs of an electrophoresis gel apparatus (Horizon 58 "GIBCO BRL - Life technologies" - EUA). TE excess was removed with filter paper to facilitate block adherence to the comb.

Normal agarose solution $(0.76 \%)$ was prepared in alkaline buffer $(0.03 \mathrm{mM} \mathrm{NaOH}$; $0.01 \mathrm{mM}$ EDTA $\mathrm{pH}$ 8.0) and heated for complete homogenization. After cooling, the solution was deposited in the gel electrophoresis chamber and the comb, containing the blocks, was fitted. Following gellification, the comb was removed, the blocks remaining in the gel, which was submitted to $7 \mathrm{~V}$ for $14 \mathrm{~h}$. Then, this was neutralized, for $1 \mathrm{~h}$, by soaking in a solution containing $30 \mathrm{mM} \mathrm{NaCl}$ and $50 \mathrm{mM}$ Tris ${ }^{\circ} \mathrm{Cl} \mathrm{pH}$ 6.0. Following this step, the gel was stained in ethidium bromide solution $(0.5 \mu \mathrm{g} / \mathrm{ml})$, for $10 \mathrm{~min}$, visualized in a transilluminator UVP (Model TM-10E-EUA), and then digitalized using Canon Power Shot S2IS. The image was analyzed using the software Image J, $1.33 \mathrm{u}$ version, in order to quantify the DNA strand breaks. The collected data were submitted to chi-square test $\left(\chi^{2}\right)$, adopting $5 \%$ as significance level.

To ascertain of $\mathrm{SnCl}_{2}$-induced lesion repair, after $40 \mathrm{~min}$ of incubation, the $\mathrm{AB} 1157$ residual fractions (control and treated, $4.5 \mathrm{ml}$ each one) were centrifuged $\left(2,940 \mathrm{xg} ; 15 \mathrm{~min} ; 4^{\circ} \mathrm{C}\right)$, suspended in fresh LB medium and incubated with shaking for $90 \mathrm{~min}$, at $37^{\circ} \mathrm{C}$. Aliquot $(1.5 \mathrm{ml})$ from each sample was taken every $30 \mathrm{~min}$. Blocks were performed and alkaline electrophoresis was carried out as described above.

\section{RESULTS AND DISCUSSION}

Previous studies pointed to that base excision repair (BER) genes are involved in cell restoration after oxidative stress (Friedberg et al., 2006). As presented elsewhere, $\mathrm{SnCl}_{2}$ is able to promote different inactivation levels in $E$. coli base excision repair mutants (Dantas et al., 1996). Stannous chloride can induce ROS (Dantas et al., 1996), in addition to a direct effect, as previously described (De Mattos et al., 2000; De Mattos et al., 2005). So, in the present study, the participation of $x t h \mathrm{~A}$ (exonuclease III) and $n f o$ (endonuclease IV) genes in the repair of $\mathrm{SnCl}_{2}$-induced lesions was observed. Bacterial DNA was analyzed through alkaline gel electrophoresis; the results have shown that $\mathrm{SnCl}_{2}$ is able to induce DNA strand breaks in all strains used (Fig. 1). 


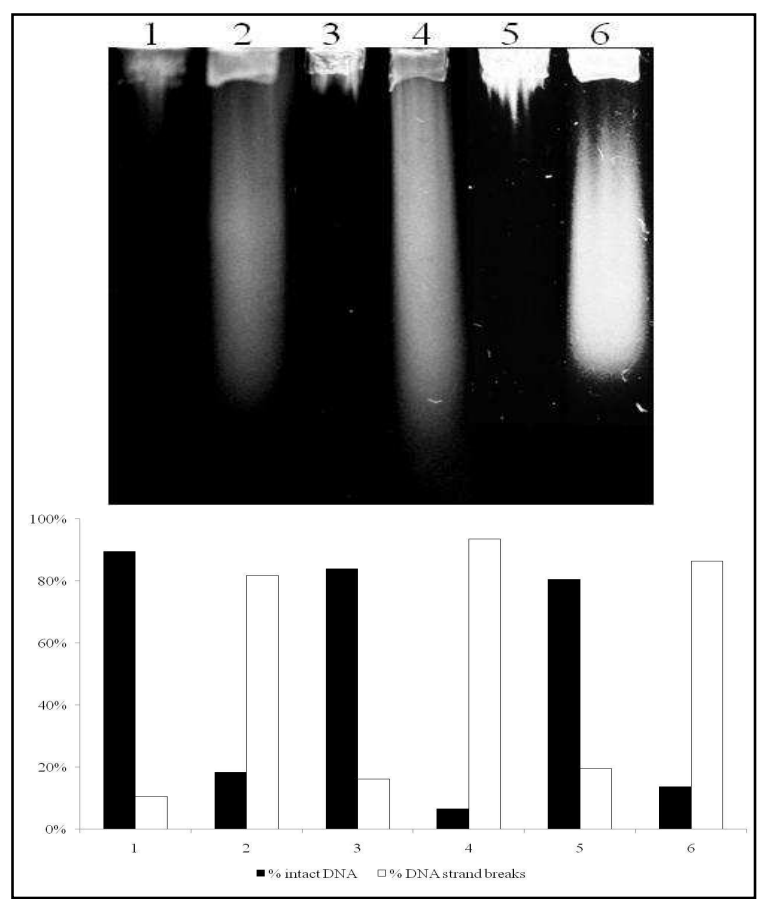

Figure 1 - Alkaline gel electrophoresis of $E$. coli with different DNA repair capacities treated with $25 \mu \mathrm{g} / \mathrm{ml} \mathrm{SnCl}$. Lanes: (1) AB1157; (2) $\mathrm{AB} 1157+\mathrm{SnCl}_{2}$; (3) BW9091; (4) BW9091 + $\mathrm{SnCl}_{2}$; (5) BW527; (6) BW527 + $\mathrm{SnCl}_{2}$.

Gel densitometrical analysis revealed that $\mathrm{AB} 1157$ was the strain displaying the lowest number of strand breaks, suggesting that this strain has an advantage regarding other strains. The performance of all base excision repair proteins would assure quick repair of $\mathrm{SnCl}_{2}$-induced lesions, with few DNA strand breaks visualized in the gel.

BER mutant alkaline gel analysis has shown that the BW9091 strain exhibited a number of strand breaks higher than both strains wild type $(\mathrm{p}<0.0001)$ and BW527 mutant $(\mathrm{p}<0,0001)$. As demonstrated by Cabral and collaborators (1998), $\mathrm{SnCl}_{2}$ is able to generate 8-hydroxyguanine lesions, and it is known that this lesion can be recognized and removed by a BER protein, called formamidopyrimidine glycosylase (Fpg) (Friedberg et al., 2006). This process generates apyrimidinic sites (Friedberg et al., 2006), which could be translated in DNA strand breaks through the present proposed methodology. Thus, these results suggest that $\mathrm{SnCl}_{2}$-induced lesions could be recognized and removed by Fpg protein, but the repair process in the mutant strain would be slower, when compared with the wild type strain, because of the lack of other BER proteins.
According to these results, we could suggest that $n f o$ gene product (endonuclease IV) seems to be more important than exonuclease III ( $x$ thA gene) in the repair of $\mathrm{SnCl}_{2}$ - induced DNA lesions, since BW527 was the strain which showed the lowest number of DNA strand breaks, when compared with all the others $(\mathrm{p}<0.0001)$. So, $\mathrm{SnCl}_{2}$ could be inducing damage, recognized preferentialy by $n f o$ gene product, as it occurs with the chemical agents tert-butil hydroperoxide and bleomicin, responsible for producing lesions not recognized by exonuclease III, but only by endonuclease IV (Friedberg et al., 2006). Experiments are carrying out, in order to confirm this hypothesis.

To demonstrate the occurrence of repair events, $\mathrm{AB} 1157$ strain aliquots, after $\mathrm{SnCl}_{2}$ treatment, were submitted to incubation for $90 \mathrm{~min}$, with the repair accompanied every $30 \mathrm{~min}$ (as described in material and methods) by a decrease of DNA strand break number (Fig. 2).

Densitometrical analysis revealed that there is lesion regression almost reaching control levels. The strand break number begins to decrease after 30 minutes of incubation ( $p<0.0001-$ Fig. 2, lanes 2 and 3 ) with lesion decrease becoming more 
evident after 90 minutes $(\mathrm{p}<0.0001$, when compared with all lanes - Fig. 2, lane 5). These results appear to be true, since AB1157 displays all the repair mechanisms active.
It is important to emphasize that the experimental approach used here seems to be appropriate to study DNA oxidative lesions and its repair in $E$. coli.

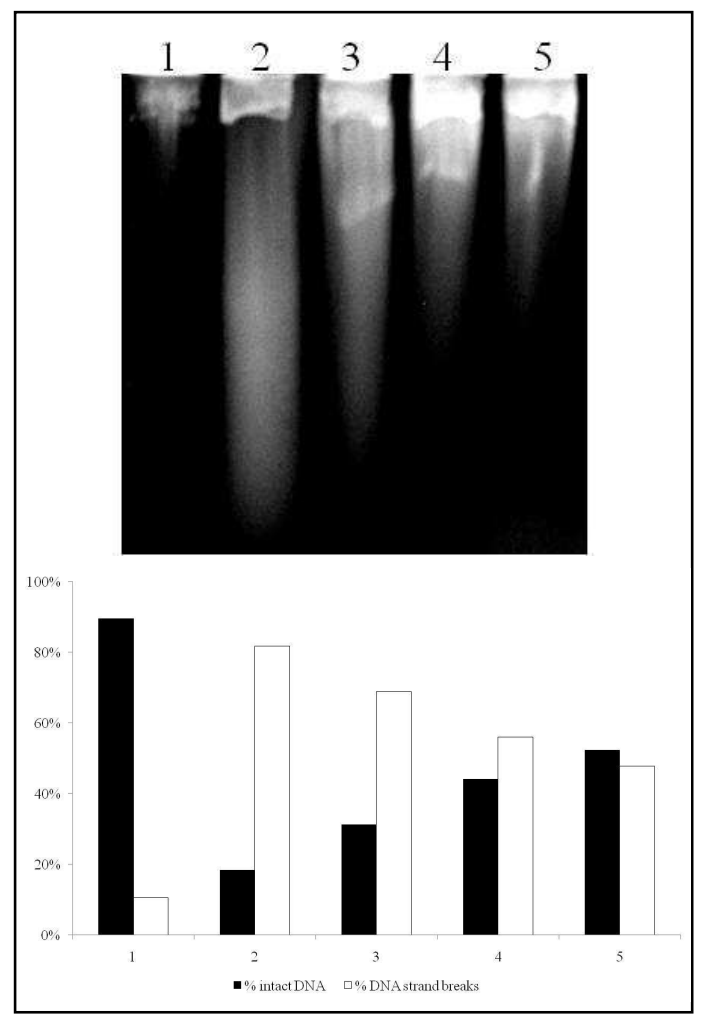

Figure 2 - Repair of $\mathrm{SnCl}_{2}$-induced lesions in E. coli $\mathrm{AB} 1157$ by alkaline gel electrophoresis. The culture was treated with $25 \mu \mathrm{g} / \mathrm{ml}$ of $\mathrm{SnCl}_{2}$, for $40 \mathrm{~min}$. Afterwards, the culture was centrifuged, suspended in LB medium and incubated for $90 \mathrm{~min}$. Aliquots were collected after $40 \mathrm{~min}$ of treatment and following every $30 \mathrm{~min}$ of incubation time. Lanes: (1) control; (2) $\mathrm{SnCl}_{2}$ after 40 min of treatment; (3) 30 min of repair; (4) $60 \mathrm{~min}$ of repair; (5) $90 \mathrm{~min}$ of repair.

Other experiments, using strains lacking one or more base excision repair enzymes, are being carried out in order to clarify the mechanism involved in $\mathrm{SnCl}_{2}$-induced lesions, as well as the repair of the damage induced by this agent.

\section{ACKNOWLEDGEMENTS}

The authors are grateful to Carlos Brown Scavarda for English language support. This work received grants from CNPq, Capes and FAPERJ (E26/171.332/2006 and E-26/171.162/2006) .

\section{RESUMO}

Espécies reativas de oxigênio (ERO) podem induzir lesões em diferentes alvos celulares, incluindo o DNA. O cloreto estanoso $\left(\mathrm{SnCl}_{2}\right)$ é um gerador de ERO que induz letalidade em E. coli, sendo o reparo por excisão de bases (BER) um mecanismo importante neste processo. Técnicas como o ensaio cometa (em eucariotos) e a eletroforese de DNA plasmidial em gel de agarose têm sido utilizadas para detectar genotoxicidade. No presente estudo, uma adaptação do método de eletroforese em gel alcalino de agarose foi usada para verificar a indução de quebras, pelo $\mathrm{SnCl}_{2}$, no DNA de E. coli, bem como a participação de enzimas do BER na restauração das lesões. Os resultados mostraram que o $\mathrm{SnCl}_{2}$ induziu quebras 
no DNA de todas as cepas testadas. Além disso, endonuclease IV e exonuclease III estão envolvidas na reparação dos danos. Em resumo, os dados obtidos indicam que a metodologia de eletroforese em gel alcalino de agarose pode ser empregada tanto para o estudo de quebras no DNA, quanto para avaliação dos mecanismos de reparação associados.

\section{REFERENCES}

Asad, N. R.; Leitão, A. C. (1991), Effects of metal ion chelators on DNA strand breaks and inactivation produced by hydrogen peroxide in Escherichia coli: detection of iron-independent lesions. J Bacteriol., 173, 2562-2568.

Cabral, R. E. C.; Leitão, A. C.; Lage, C.; Caldeira-deAraujo, A.; Bernardo-Filho, M.; Dantas, F. J. S.; Cabral-Neto, J. B. (1998), Mutational potentiality of stannous chloride: an important reducing agent in the Tc-99m-radiopharmaceuticals. Mutat Res., 408, 129135.

Caldeira-de-Araujo, A.; Dantas, F. J. S.; Moraes, M. O.; Felzenszwalb, I.; Bernardo-Filho, M. (1996), Stannous chloride participates in the generation of reactive oxygen species. Free Radical Research in Latin America, 48, 109-113.

Cooke, M. S.; Evans, M. D.; Dizdaroglu, M.; Lunec, J. (2003), Oxidative DNA damage: mechanisms, mutation and disease. FASEB J., 17, 1195-1210.

Dantas, F. J. S.; Moraes, M. O.; Carvalho, E. F.; Valsa, J. O.; Bernardo-Filho, M.; Caldeira-de-Araujo, A. (1996), Lethality induced by stannous chloride on Escherichia coli AB1157: participation of reactive oxygen species. Food Chem Toxicol., 34, 959-962.

Dantas, F. J. S.; Moraes, M. O.; De Mattos, J. C. P.; Bezerra, R. J. A. C.; Carvalho, E. F.; Bernardo-Filho, M.; Caldeira-de-Araujo, A. (1999), Stannous chloride mediates single strand breaks in plasmid DNA through reactive oxygen species formation. Toxicol Lett., 110, 129-136.

De Mattos, J. C. P.; Dantas, F. J. S.; Bezerra, R. J. A. C.; Bernardo-Filho, M.; Cabral-Neto, J. B.; Lage, C.; Leitão, A. C.; Caldeira-de-Araujo, A. (2000), Damage induced by stannous chloride in plasmid DNA. Toxicol Lett., 116, 159-163.

De Mattos, J. C. P.; Dantas, F. J. S.; Caldeira-deAraujo, A.; Moraes, M. O. (2004), Agarose Gel Electrophoresis System in the Classroom. Biochem Mol Biol Education, 32, 254-257.

Mattos, J. C. P.; Lage, C.; Dantas, F. J. S.; Moraes, M. O.; Nunes, A. P. M.; Bezerra, R. J. A. C.; Faria, M. V. C.; Leitão, A. C.; Caldeira-de-Araujo, A. (2005), Interaction of stannous chloride leads to alteration in DNA, triphosphate nucleotides and isolated bases. Mol Cell Biochem., 280, 173-179.
Friedberg, E. C.; Walker, G. C.; Sied, W.; Wood, R. D.; Schultz, R. A.; Ellenberger, T. (2006), DNA Repair and Mutagenesis. ASM Press, Washington.

Halliwell, B.; Whiteman, M. (2004), Measuring reactive species and oxidative damage in vivo and in cell culture: how should you do it and what do the results means? Br J Pharmacol., 142, 231-255.

Kehrer, J. P. (2000), The Haber-Weiss reaction and mechanisms of toxicity. Toxicology, 149, 43-50.

Luria, S. E.; Burrous, J. W. (1957), Hybridization between E. coli and Shigella. J. Bacteriol., 74, 461476.

MacGrath, R. A.; Williams, R. (1966), Reconstruction in vivo of irradiated Escherichia coli deoxyribonucleic acid, the rejoining of broken pieces. Nature, 212, 532-535.

Marnett, L. J. (2000), Oxyradicals and DNA damage. Carcinogenesis, 21(3), 361-370.

Ostling, O.; Johanson, K. J. (1984), Microelectrophoretic study of radiation-induced DNA damage in individual mammalian cells. Biochem Biophys Res Commun., 123, 291-298.

Saha, G. B. (1998), Fundamentals of Nuclear Pharmacy. Springer Verlag, New York.

Santos-Filho, S. D.; Fonseca, A. S.; Bernardo-Filho, M. (2007), The male reproductive system and the effect of an extract of a medicinal plant (Hypericum perforatum) on the labeling process of blood constituents with Technetium-99m. Braz Arch Biol Technol., 50, 97-104.

Singh, N. P.; McCoy, M. T.; Tice, R. R.; Schneider, E. L. (1988), A simple technique for quantification of low levels of DNA damage in individual cells. Exp Cell Res., 175, 184-191.

Tice, R. R.; Agurell, E.; Anderson, D.; Burlinson, B.; Hartmann, A.; Kobayashi, H.; Miyamae, Y.; Rojas, E.; Ryu, J. C.; Sasaki, Y. F. (2000), Single cell gel/comet assay: guidelines for in vitro and in vivo genetic toxicology testing. Environ Mol Mutagen., 35, 206-221.

Zirkle, R. E.; Krieg, N. R. (1996), Development of a method based on alkaline gel electrophoresis for estimation of oxidative damage to DNA in Escherichia coli. J Appl Bacteriol., 81, 133-138.

Received: August 21, 2008; Accepted: September 01, 2008. 